Endocrinol. Japon. 1987, 34 (Suppl. No. 1), 31-37

\title{
Interaction between GRF and somatostatin in regulation of GH secretion
}

\author{
TAmotsu SHIBASAKI, Akitsugu MASUDA, Toshiniro IMAKI, \\ NAOKO YAMAUCHI, HIROSHI DEMURA AND \\ KAzUo SHIZUME
}

\begin{abstract}
Department of Medicine, Institute of Clinical Endocrinology, Tokyo Women's Medical College, 8-1 Kawada-cho, Shinjuku-ku, Tokyo 162, Japan
\end{abstract}

Growth hormone (GH) secretion from the pituitary is under the dual control of growth hormone-releasing factor (GRF) and somatostatin. In addition to these antagonistic peptides, several other feedback mechanisms are involved in the regulation of $\mathrm{GH}$ secretion. For instance, GH itself stimulates somatostatin release from the hypothalamus (1). Insulin-like growth factor-I (IGF-I), which is synthesized in the liver, acts on both the hypothalamus and the pituitary to stimulate somatostatin release (2) and to suppress basal and GRFinduced GH secretion (3), respectively. Furthermore, we have recently found that IGF-I suppresses GRF release from the rat hypothalamic fragments in vitro (4).

Plotsky and Vale have recently found that GRF concentration in the hypophysial portal blood changes in a reverse manner to that of somatostatin in rat (5). Very recently, Aguila and McCann have reported that GRF stimulates somatostatin release from rat hypothalamic fragments (6). These findings suggest a possibilility of interaction of GRF to somatostatin in the hypothalamic level. We therefore tried to speculate about the interaction between GRF and somatostatin by examining the effect of GRF administration on plasma $\mathrm{GH}$ and TSH levels in man and the effect of somatostatin on GRF release from rat hypothalamus in vitro.

Fig. 1 shows the effect of infusion of $1 \mathrm{mg}$ GRF for $150 \mathrm{~min}$ on plasma GH response to subsequent $100 \mu \mathrm{g}$ GRF administration in man. Plasma GH levels were gradually elevated after the start of infusion and plateaued in $30 \mathrm{~min}$. One hundred $\mu \mathrm{g}$ of GRF administered at $150 \mathrm{~min}$ induced no significant GH rise. As shown in the upper panel of Fig. 2, a prior bolus injection of $50 \mu \mathrm{g}$ GRF increased plasma GH with a peak of $23.9 \pm 7.9 \mathrm{ng} / \mathrm{ml}$ at $30 \mathrm{~min}$ and the plasma GH levels were then gradually lowered during the following $90 \mathrm{~min}$. However, no significant rise of plasma GH levels was found after $100 \mathrm{~g}$ GRF administration. The same tendency was observed in the administration of $200 \mu \mathrm{g}$ GRF $2 \mathrm{hr}$ after the prior injection of $100 \mu \mathrm{g}$ GRF as shown in the lower panel. Two hundreds $\mu \mathrm{g}$ GRF did not induce a significant plasma $\mathrm{GH}$ rise.

There are several possibillities to explain the inhibition of $\mathrm{GH}$ response to the subsequent GRF by the prior GRF administration. The first possibility is that depletion of releasable $\mathrm{GH}$ might occur as the result of $\mathrm{GH}$ secretion induced by the prior GRF 


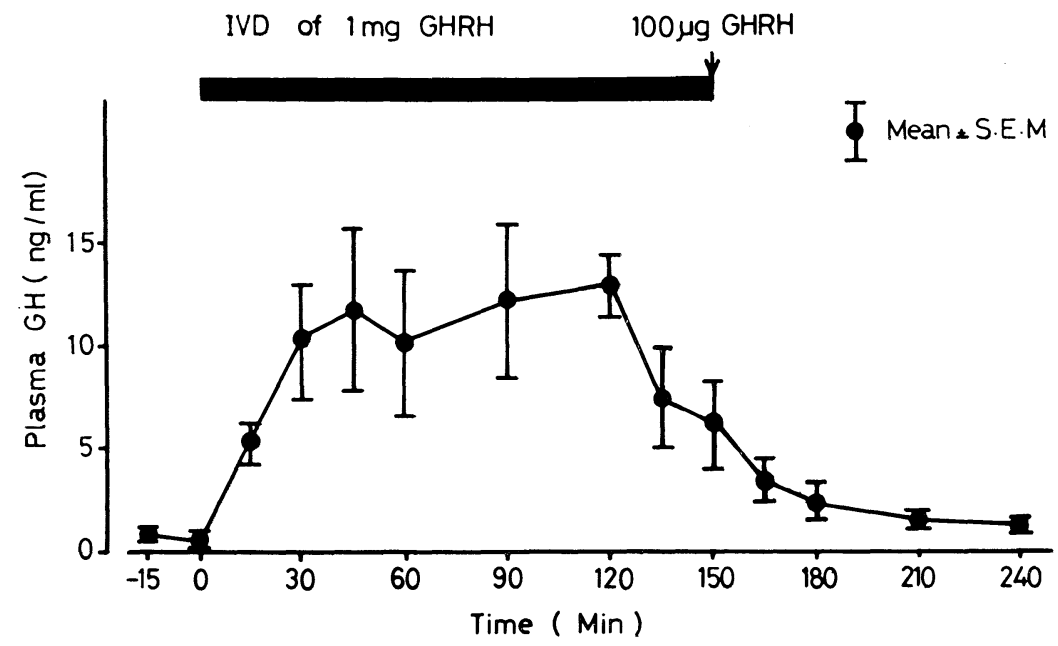

Fig. 1. Plasma GH responses to infusion of $1 \mathrm{mg}$ GRF and iv administration of $100 \mu \mathrm{g}$ GRF in normal men.

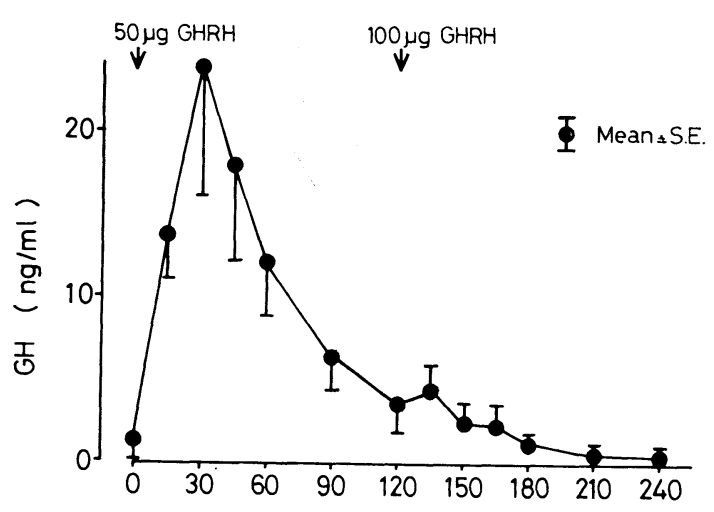

administration. However, this is unlikely because, as shown in the bottom panel of Fig. 3, a high GH peak was observed in insulin-induced hypoglycemia even after the prior administration of $200 \mu \mathrm{g}$ GRF (7). Second, down-regulation of GRF receptors might occur because Vale and his coworkers have reported that number of GRF binding sites of rat anterior pituitary cells decreases after $2 \mathrm{hr}$ of exposure to $0.5 \mathrm{nM}$ GRF (8). Finally, increase in somatostatin release might be induced by the prior GRF administration.

It is difficult to speculate from the

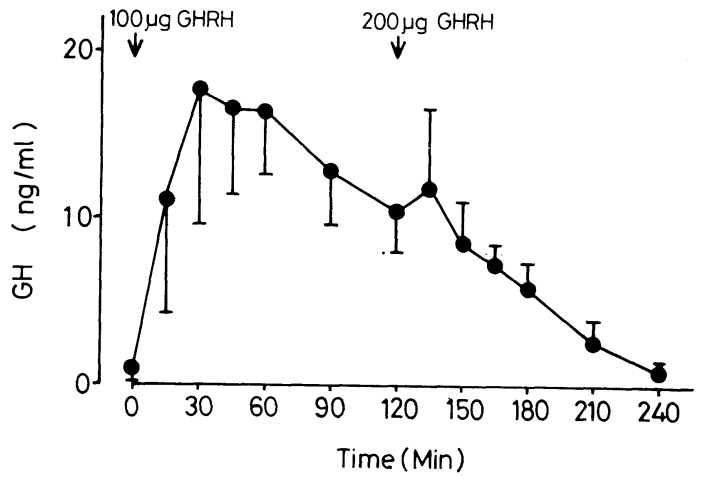

Fig. 2. Plasma GH responses to iv administrations of GRF in normal men. peripheral plasma somatostatin levels the manner of somatostatin release from the hypothalamus because most somatostatin in the peripheral blood is throught to originate from the peripheral tissues such as the gut and the pancreas. Several groups have reported the suppressive effect of somatostatin on basal and TRH-induced TSH secretion in man and rat $(9,10,11$, 12). Therefore, we tried to monitor indirectly somatostatin release from the hypothalamus by measuring plasma TSH levels based on the the assumption that somatostatin suppresses TSH secretion. 

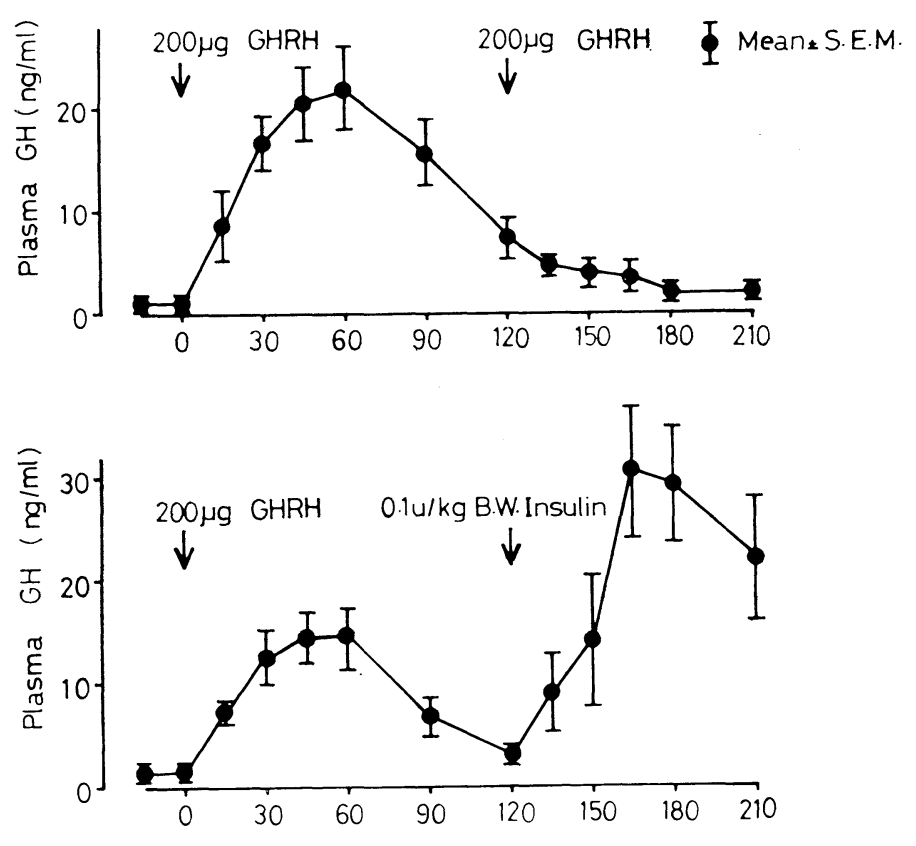

Fig. 3. Plasma $\mathrm{GH}$ responses to to $200 \mu \mathrm{g}$ GRF and insulininduced hypoglycemia in men.

Fig. 4 shows the effect of GRF administration on plasma GH and TSH levels in man. The intravenous administration of normal saline did not affect the plasma TSH and GH levels as shown in the left upper panel. On the other hand, the iv administration of $50 \mu \mathrm{g}$ GRF increased plasma GH levels from $1.3 \pm 0.9 \mathrm{ng} / \mathrm{ml}$ to $17.6 \pm 8.3 \mathrm{ng} / \mathrm{ml} 30 \mathrm{~min}$ after the injection, but no significant change in the plasma TSH levels was found during $2 \mathrm{hr}$ after the injection. The administration of $100 \mu \mathrm{g}$ GRF elevated plasma GH level from $0.9 \pm 0.6 \mathrm{ng} /$ $\mathrm{ml}$ to $17.6 \pm 8.3 \mathrm{ng} / \mathrm{ml} 30 \mathrm{~min}$ after the injection and significantly lowered plasma TSH level from the basal level of $1.9 \pm 0.3$ $\mu \mathrm{U} / \mathrm{ml}$ to $1.6 \pm 0.3 \mu \mathrm{U} / \mathrm{ml} 120 \mathrm{~min}$ after the injection. Furthermore, $200 \mu \mathrm{g}$ GRF induced elevation of plasma GH level and significantly lowered plasma TSH level from the basal level of $1.9 \pm 0.2 \mu \mathrm{U} / \mathrm{ml}$ to $1.5 \pm 0.2$ $\mu \mathrm{U} / \mathrm{ml}$ at $90 \mathrm{~min}$ and to $1.3 \pm 0.1 \mu \mathrm{U} / \mathrm{ml}$ at $120 \mathrm{~min}$.
These results suggest the intervention of somatostatin in the suppression of plasma TSH level. Three possibilities may be raised to explain the mechanism of somatostatin release after GRF administration. First, GH secreted in response to GRF administration induces somatostatin release from the hypothalamus since it has been reported that $\mathrm{GH}$ stimulates somatostatin release in rat (1). If it is the case, the administration of $50 \mu \mathrm{g}$ GRF also should induce decrease in plasma TSH levels since $50 \mu \mathrm{g}$ of GRF elevated plasma GH levels to the same extent as that of $100 \mu \mathrm{g}$ or $200 \mu \mathrm{g}$ GRF. But, no significant change in plasma TSH levels was found with the administration of $50 \mu \mathrm{g}$ GRF. Even though no significant change in plasma TSH levels was found, there is still the possibility that somatostatin release is stimulated in response to increase in GH secretion. Because the sensitivity of thyrotroph to somatostatin is lower than that of somatotroph (9), the 

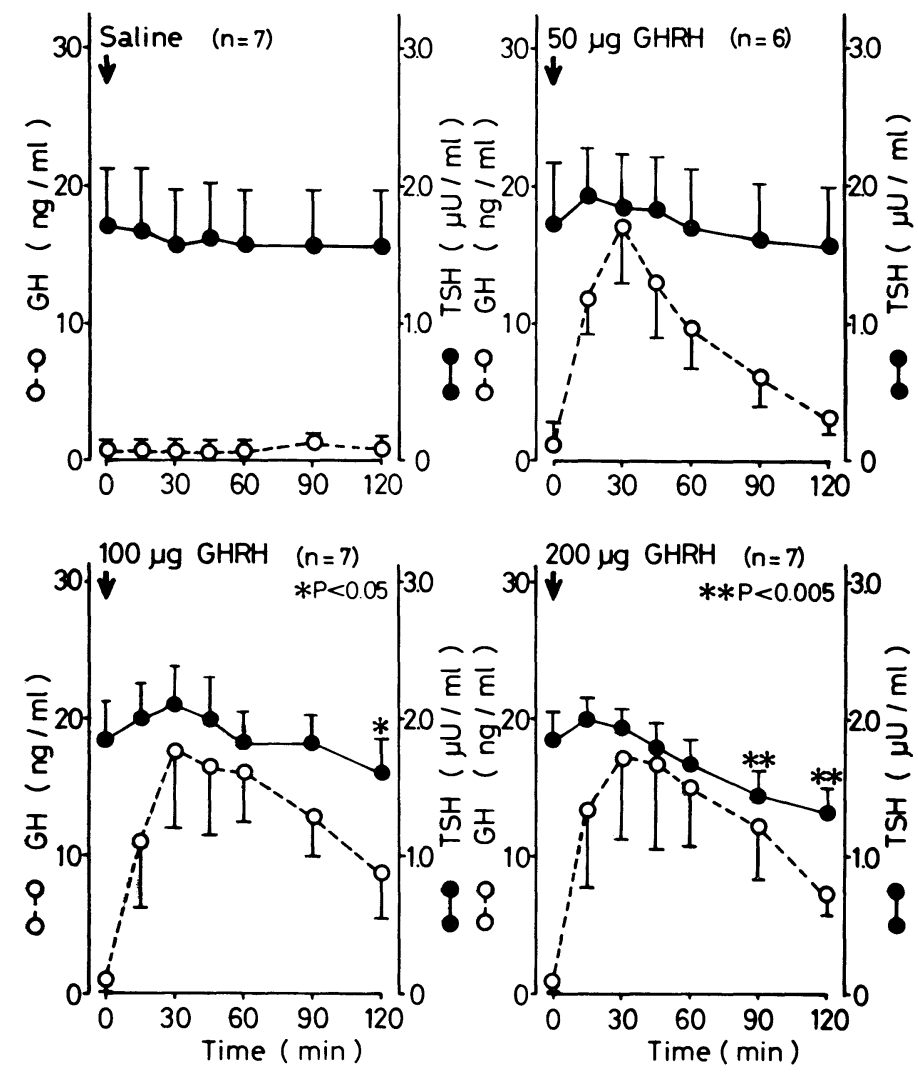

Fig. 4. Plasma GH and TSH responses to iv administration of GRF in normal men. change in plasma TSH levels may not reflect efficiently the change in somatostatin release.

The second possible explanation is that administered GRF itself directory acts on the hypothalamus and stimulates the release of somatostatin since an vitro study has shown that GRF stimulates somatostatin release from rat hypothalamus (6). This possibility is strongly suggested by our result that only the administration of $100 \mu \mathrm{g}$ and $200 \mu \mathrm{g}$ GRF decreased TSH secretion and that $200 \mu \mathrm{g}$ GRF decreased TSH secretion more significantly.

The third possible explanation is that both GH and GRF together may stimulate somatostatin release from the hypothalamus. Since the median eminence is outside blood brain barrier, $\mathrm{GH}$ and administered GRF can reach the median eminence to stimulate somatostatin release.

Fig. 5 shows the change in plasma TSH and $\mathrm{GH}$ levels when iv bolus injection of GRF was repeated. The prior $100 \mu \mathrm{g}$ GRF injection induced a plasma $\mathrm{GH}$ peak of $23.1 \pm 10.8 \mathrm{ng} / \mathrm{ml}$ at $30 \mathrm{~min}$ and a significant suppression of plasma TSH level at $120 \mathrm{~min}$. The following $200 \mu \mathrm{g}$ GRF administration induced a low $\mathrm{GH}$ peak at $135 \mathrm{~min}$ and a significant lowering of plasma TSH level at $240 \mathrm{~min}$. It is therefore suggested that GRF rather than GH has a greater role to stimulate somatostatin release from the finding that the second administration of $200 \mu \mathrm{g}$ GRF significantly suppressed TSH level in spite of extremely low 


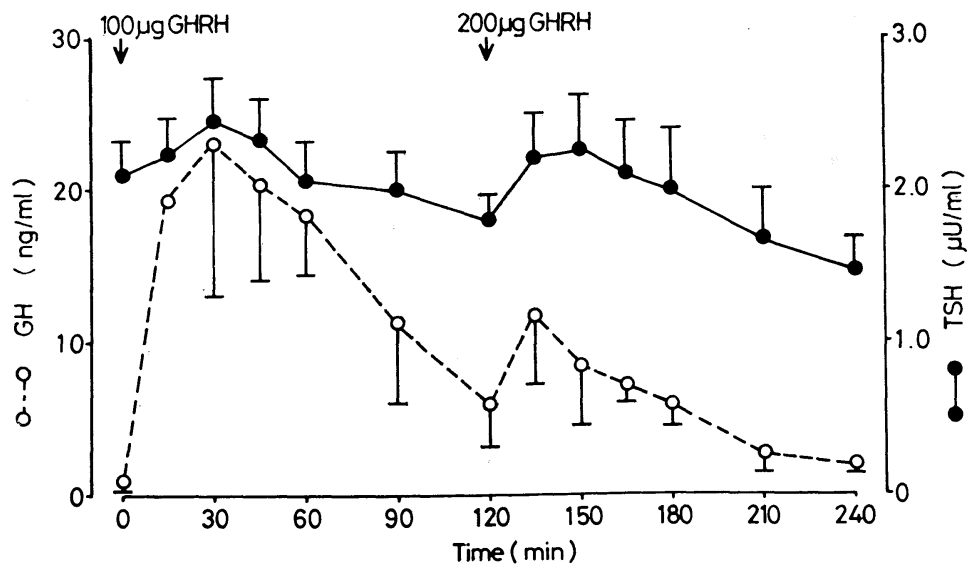

Fig. 5. Changes in plasma $\mathrm{GH}$ and TSH levels in iv administration of GRF in normal men.

plama $\mathrm{GH}$ rise induced.

We examined the effect of somatostatin on GRF release from rat hypothalamic fragments in vitro. Hypothalamic fragments obtained from male Wistar rats weighing approximately $200 \mathrm{~g}$ were incubated in Krebs Ringer bicarbonate buffer supplemented with $0.1 \%$ BSA and $0.5 \%$ glucose under an atmosphere of $5 \% \mathrm{CO}_{2}$ and $95 \% \mathrm{O}_{2}$ at $37^{\circ} \mathrm{C}$ for $30 \mathrm{~min}$. After the preincubation, each hypothalamic fragment was incubated with fresh buffer with sample solution for another 30 min. The concentration of immunoreactive GRF in the medium was measured with a specific and sensitive radioimmunoassay. The results of the suppressive effects of somatostatin 14 and somatostatin
28 on GRF release are shown in Table 1. Somatostatin 14 significantly suppressed GRF release from the rat hypothalamic fragments to $87.1 \%, 86.5 \%$ and $83.0 \%$ that of the control at concentrations of $10^{-10}$, $10^{-9}$ and $10^{-8} \mathrm{M}$, respectively. Somatostatin 28 also significantly decreased GRF release to $87.7 \%, 82.8 \%$ and $76.5 \%$ that of the control at concentrations of $10^{-10}, 10^{-9}$ and $10^{-8} \mathrm{M}$, respectively. The concentration of somatosatatin in the hypophysial portal blood was reported to be several hundred $\mathrm{pg} / \mathrm{ml}$ corresponding to the order of $10^{-10}$ $M$ (13). These results, therefore, suggest that somatostatin acts on the hypothalamus to suppress GRF release.

The site of somatostatin action is pre-

Table 1. The effects of SS-14 and SS-28 on GRF release

\begin{tabular}{|c|c|c|c|c|c|c|}
\hline \multirow[b]{3}{*}{$\begin{array}{l}\text { IR-GRF } \\
(\text { pg/hypo/30 min) }\end{array}$} & \multicolumn{6}{|c|}{ somatostatin $14(\mathrm{M})$} \\
\hline & control & $10^{-12}$ & $10^{-11}$ & $10^{-10}$ & $10^{-9}$ & $10^{-8}$ \\
\hline & $98.0 \pm 3.3$ & $100.1 \pm 4.6$ & $93.1 \pm 3.8$ & $85.4 \pm 3.6^{*}$ & $84.8 \pm 1^{* *} .3$ & $81.3^{* *} \pm 3.1$ \\
\hline & \multicolumn{6}{|c|}{ Somatostatin $28(\mathrm{M})$} \\
\hline & control & $10^{-12}$ & $10^{-11}$ & $10^{-10}$ & $10^{-9}$ & $10^{-8}$ \\
\hline $\begin{array}{l}\text { IR-GRF } \\
\text { (pg/hypo/30 min) }\end{array}$ & $98.0 \pm 3.3$ & $97.9 \pm 3.1$ & $91.7 \pm 3.6$ & $85.9 \pm 1.1^{*}$ & $81.1 \pm 1.9$ & $75.0 \pm 3.3$ \\
\hline
\end{tabular}


sumably the median eminence. However, there may be interactions between GRF neurons and somatostatin neurons in the hypothalamus because somatostatin-positive fibers exist in the arcuate nucleus where GRF neurons are present (14). Our clinical study and the report by Aguila and McCann (6) that GRF stimulates somatostatin release from the rat hypothalamus suggest presence of GRF action on somatostatin release in the hypothalamic level. The median eminence is a possible site where GRF and somatostatin are released into the hypophysial portal blood because GRF-positive fibers end at the same area as somatostatinpositive fibers end (15). Somatostatin neurons may be innervated by GRF neurons because GRF-positive fibers have been found in the preoptic anterior hypothalamic area where somatostatin neurons are present (16). Somatostatin in the area is considered to be important for the regulation of $\mathrm{GH}$ secretion.

Our results suggest that interactions between GRF and somatostatin exist not only at the pituitary level but also at the hypothalamic level in the regulatory mechanism of $\mathrm{GH}$ secretion.

\section{References}

1. Sheppard MC, Kronheim S, Pimstone BL 1978. Stimulation by growth hormone of somatostatin release from the rat hypothalamus in vitro. Clin Endocrinol 9, 583.

2. Berelowitz M, Szabo M, Frohman LA, Firestone S, Chu L, Hintz RL 1981 Somatomedin $\mathrm{C}$ mediates growth hormone negative feedback by effects on both the hypothalamus and the pituitary. Science 212, 1279.

3. Brazeau $\mathbf{P}$, Gillemin $\mathbf{R}$, Ling $\mathbf{N}$, Van Wyk J, Humbel R 1982. Inhibition par les somatomédines de la sécrétion de l'hormone de croissance stimulée par le factuer hypothalamique somatocrinine (GRF) ou le peptide de synthèse hpGRF. CR Acad Sc Paris (111) 295, 651.
4. Shibasaki T, Yamauchi N, Hotta M, Masuda A, Imaki T, Demura, H, Ling N, Shizume K 1986. In vitro release of growth hormonereleasing factor from rat hypothalamus: effect of insulin-like growth factor-1. Regul Peptides 15, 47.

5. Plotsky PM, Vale W 1985. Patterns of growth hormone-releasing factor and somatostatin secretion into the hypophysial-portal circulation of the rat. Science 230, 461.

6. Aguila MC, McCann SM 1985. The influences of hGRF, CRF, TRH and LHRH on SRIF release from median eminence fragments. Brain Res 348, 180.

7. Shibasaki $T$, Hotta $M$, Masuda A, Imaki $T$. Obara N, Demura H, Ling N, Shizume K 1985. Plasma GH responses to GHRH and insulin-induced hypoglycemia in man. $J$ Clin Endocrinol Metab 60, 1265.

8. Bilezikjian LM, Seifert H, Vale W 1986. Desensitization to growth hormone-releasing factor (GRF) is associated with downregulation of GRF-binding sites. Endocrinology 118, 2045.

9. Vale W, Rivier C, Brazeau P, Guillemin R 1974. Effects of somatostatin on the secretion of thyrotropin and prolactin. Endocrinology 95, 968.

10. Siler TM, Yen SSC, Vale W, Guillemin R 1974. Inhibition by somatostatin on the release of TSH induced in man by thyrotropin-releasing factor. J. Clin Endocrinol Metab 38, 742.

11. Ferland L, Labrie, F, Jobin M, Arimura A, Schally AV 1976. Physiological role of somatostatin in the control of growth hormone and thyrotropin secretion. Biochem Biophy Res Commun 68, 149.

12. Chihara K, Arimura A, Chihara M, Schally AV 1978. Studies on the mechanism of growth hormone and thyrotropin responses to somatostatin antiserum in anesthetized rats. Endocrinology 103, 1916.

13. Chihara K, Arimura A, Schally AV 1979. Immunoreactive somatostatin in rat hypophyseal portal blood: effects of anesthesics. Endocrinology 104, 1434.

14. Ohtsuka M, Hisano S, Daikoku S 1983. Electronmicroscopic study of somatostatincontaining neurons in rat arcuate nucleus with special reference to neuronal regulation. Brain Res 263, 191.

15. Bresson J-L, Clavequin M-C, Fellmann D, 
Bugnon C 1984. Ontogeny of the neuroglandular system revealed with hpGRF44 antibodies in human hypothalamus. Neuroendocrinology 39, 68.
16. Smith RM, Howe PRC, Oliver JR, Willoughby JO 1984. Growth hormone releasing factor immunoreactivity in rat hypothalamus. Neuropeptides 4, 109. 